\title{
Mucinous breast carcinoma presenting as Paget's disease of the nipple in a man: A case report
} Dimitrios Peschos ${ }^{1}$, Elena Tsanou4, Pavlos Dallas ${ }^{3}$, Konstantinos Charalabopoulos*2, Christos Kanaris ${ }^{5}$ and Anna Batistatou ${ }^{3}$

Address: ${ }^{1}$ Dept. of Forensic Science, Medical Faculty, University of Ioannina, Ioannina, Greece, ${ }^{2}$ Dept. of Physiology, Clinical Unit, Medical Faculty, University of Ioannina, Ioannina, Greece, ${ }^{3}$ Dept. of Pathology, Medical Faculty, University of Ioannina, Ioannina, Greece, ${ }^{4} \mathrm{Cytology}$ Laboratory, K Frontzou 7, Ioannina, Greece and ${ }^{5}$ Gynecologist, C. Tricoupi 6, Ioannina, Greece

Email: Dimitrios Peschos - dpeschos@cc.uoi.gr; Elena Tsanou - gorezis@hotmail.com; Pavlos Dallas - dpeschos@cc.uoi.gr; Konstantinos Charalabopoulos* - kcharala@cc.uoi.gr; Christos Kanaris - dpeschos@cc.uoi.gr; Anna Batistatou - kcharala@cc.uoi.gr

* Corresponding author

Published: 24 October 2008

Diagnostic Pathology 2008, 3:42 doi:10.1186/1746-1596-3-42
Received: 23 June 2008

Accepted: 24 October 2008

This article is available from: http://www.diagnosticpathology.org/content/3/1/42

(c) 2008 Peschos et al; licensee BioMed Central Ltd.

This is an Open Access article distributed under the terms of the Creative Commons Attribution License (http://creativecommons.org/licenses/by/2.0), which permits unrestricted use, distribution, and reproduction in any medium, provided the original work is properly cited.

\begin{abstract}
Introduction: Male breast cancer is rare compared to its female counterpart representing less than $1 \%$ of cancer in men. Moreover, mucinous carcinoma of the male breast is an extremely rare histological subtype of malignancy. Paget's disease of the nipple is rarely observed in males.
\end{abstract}

Case report: Herein, we describe a unique case of an 86 years old man with mucinous breast cancer presenting as Paget's disease of the nipple. According to the immunohistochemical evaluation the neoplastic cells were positive for estrogen (ER) and progesterone receptors (PR).

Conclusion: To our best knowledge this is the first case of mucinous male breast cancer presenting as Paget's disease of the nipple.

\section{Background}

The existing epidemiological data confirms the infrequency of male breast cancer (MBC) which represents $1 \%$ of all breast cancers $[1,2]$ Overall, the epidemiology of MBC presents similarities with the epidemiology of female breast cancer (FBC). Major genetic factors associated with an increased risk of breast cancer for men include BRCA2 mutations, which are believed to account for the majority of inherited breast cancer in men [3], Klinefelter syndrome, and a family history. Suspected genetic factors include AR gene mutations, CYP17 polymorphism, Cowden syndrome, and CHEK2 [3]. Epidemiologic risk factors for $\mathrm{MBC}$ include disorders relating to hormonal imbalances, such as obesity, testicular disorders (e.g., cryptorchidism, mumps orchitis, and orchiectomy), and radiation exposure. Suspected epidemiologic risk fac- tors include prostate cancer, prostate cancer treatment, gynecomastia, occupational exposures (e.g., electromagnetic fields, polycyclic aromatic hydrocarbons, and high temperatures), dietary factors (e.g., meat intake and fruit and vegetable consumption), and alcohol intake [3].

Paget's disease presents as an eczematous change of the nipple and areola [4]. Specifically, it is characterized by a red, oozing, crusted lesion which is often unresponsive to topical steroid and antibiotics. There is almost always present an underlying breast carcinoma. The prevalence of an associated cancer ranges from $67-100 \%$ with most studies reporting the presence of a concurrent malignancy in over $90 \%$ of patients [5]. Most commonly, this is an infiltrating ductal carcinoma but occasionally a ductal carcinoma in situ (DCIS) may be present [4]. Overall, this 
type of cancer is rare, comprising $3 \%$ to $5 \%$ of all mammary malignancies [6].

To our best knowledge, about 30 cases of mucinous MBC and about 50 cases of Paget's disease of the male breast have been until now reported in the English literature [79]. Furthermore, the presentation of the mucinous breast carcinoma as Paget's disease of the male breast is considered to be unique.

\section{Case presentation}

An 86-year-old man with no medical history presented with a persistent erythema, oozing and scaling of the left nipple. The lesion was initially characterized as mammary Paget's disease, based on clinical signs. Additionally, there was no history of predisposing factors to breast lesions such as drug use (i.g. prostate cancer treatment), gynecomastia or hormonal imbalances, such as obesity and/or testicular disorders. Physical examination revealed a mass localized in the subareolar area. Fine needle aspiration biopsy was performed on the mass and malignancy was revealed on histopathological examination. The diagnosis was made after the histological examination of a breast gland segment $(14 \times 11 \times 6 \mathrm{~cm}$ in size $)$ covered by a spindle-shaped skin $(13 \times 9 \mathrm{~cm}$ in size $)$ bearing the nipple. The mass was well circumscribed $5 \times 7 \times 6 \mathrm{~cm}$ in size of soft and friable consistency with mucoid texture. The result from the histological examination revealed mucinous carcinoma of the breast gland (grade II) (Figure 1). The diagnosis was based on the presence of large amounts of extracellular mucin, in the background and detached epithelial tumor ceels in trabecular and micro papillary formations. Fibrous stroma was sparse. Immunohistochemical evaluation revealed that the neoplastic cells were positive for estrogen (ER) (Figure 2) and progesterone receptors $(\mathrm{PR})$. Therapeutically, after the modified radical

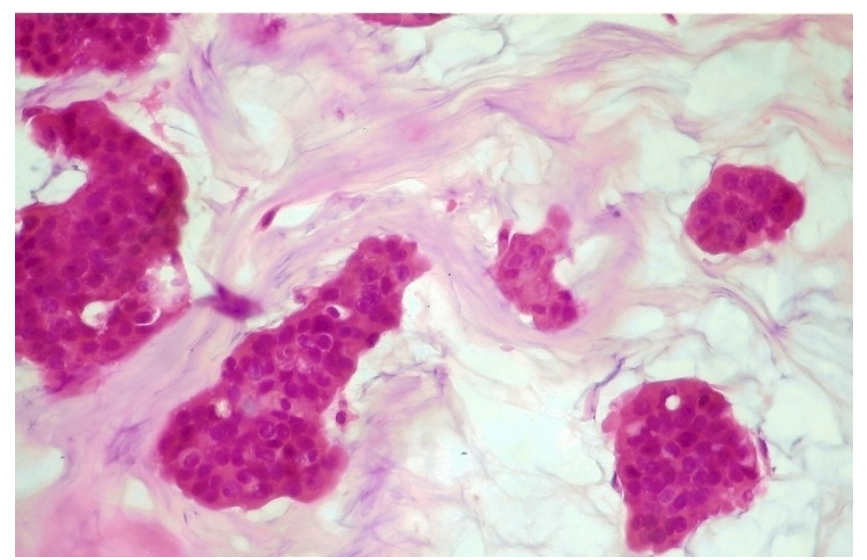

Figure I

Histological evaluation revealed the presence of mucinous carcinoma $(\mathrm{H}+\mathrm{E}, \times \mathbf{4 0 0})$.

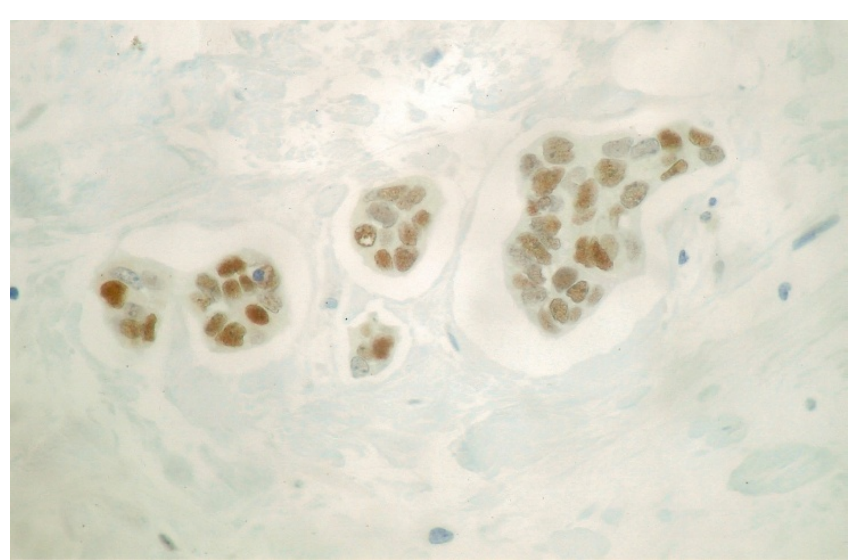

Figure 2

The neoplastic cell expressed ER\&\#945 receptors (DAB \&\#2 I 5 400)

mastectomy chemotherapy and tamoxifen was administered.

\section{Discussion}

MBC constitutes less than 1\% of all breast cancer cases $[1,2]$. Mucinous or colloid breast cancer is considered to be a rare subtype of breast cancer (invasive ductal breast cancer) and probably slightly more uncommon in men than in women [10]. Special types such as Paget's disease of the nipple and mucinous breast cancer in a man are extremely rare. To our best knowledge this is the first case reported of mucinous male breast cancer presenting as Paget's disease of the nipple.

We must emphasize that Paget's disease must be differentiated from other skin disorders, such as eczema, and it is usually the presence of an underlying lump that indicates the invasive nature of the lesion. In addition, melanoma and adenoma of the nipple may rarely mimic Paget's disease. The correct diagnosis requires histopathologic interpretation, as clinical signs may be similar.

According to the immunohistochemical analysis the cancer cells were estrogen and progesterone receptor positive. Studies have shown that MBC is more likely to be of high grade at presentation time, affecting mostly elderly males, with retained expression of ER and PR [2,10-13]. In our case reported herein, the patient was 86 years old. In specific, the majority of cancers arising in the male breast are ER positive although this finding does not correlate with a better prognosis, as it occurs in women [14,15] Clinical responses to hormonal therapy have been observed in the $\mathrm{ER}+$ patients but not in one ER - patient [16]. In women, ER expression is usually a marker of differentiation and indicates that the cancer still remains under hormonal influence. This characteristic would also imply that the 
tumor should be less aggressive and more responsive to hormone therapy. In men, however, ER-positive tumors are associated with higher stage disease [15]. Postmenopausal women have been found to have tumors that are more likely to be hormone receptor expressers as well and follow a more indolent course [17]. One possibility is that hormone receptor-positive cancers are a consequence of aberrant steroid receptor up-regulation in the estrogenstarved postmenopausal setting. The tumors over expressing the steroid receptor may have constitutive activation of downstream targets. The fact that most cancers arising in male breasts are ER positive is likely due to the lack of circulating estrogen in the male system, much like in postmenopausal women [2]. Apart from steroid receptors other immunohistochemical differences between male and female breast cancer must also be considered. For instance, cases of MBC are less likely to overexpress p53 and Erb-B2, which are associated with survival and cell proliferative activity than the female counterparts [2].

It appears that $\mathrm{MBC}$ has a more aggressive clinical behavior than FBC with a worse outcome when compared stage for stage $[18,19]$. Some studies referred to worse prognosis in men mainly due to anatomic factors (i.e., paucity of breast tissue and close tumor proximity to skin and nipple, facilitating dermal lymphatic spread and early regional and distant metastasis) and delayed diagnosis $[13,18,20]$. Usually, in MBC symptoms are often delayed and the lag time between first symptoms and surgery in some cases is twice as long as in women [21]. In the case reported herein, the mammary Paget-like lesion of the skin bearing the nipple was the main symptom. On the other hand, numerous studies have shown that breast carcinoma in males is not biologically more aggressive than in females and the prognosis of patients with breast cancer is the same in male and female patients when disease-specific survival rate, tumour size and axillary involvement are compared [22-24].

Modified radical mastectomy, combined with sentinelnode biopsy by experienced teams, is the standard treatment in case of MBC. Criteria for adjuvant systemic treatment are identical for men and women, although hormonal therapy (tamoxifen) has a more prominent place in the adjuvant setting because of the high percentage of positive hormone receptors in men [25].

Owing to its infrequent occurrence, knowledge of the etiology, pathology, immunophenotype and behavior of MBC lags behind that regarding FBC. Numerous studies have confirmed distinct differences in the genetic basis of $\mathrm{MBC}$ and FBC $[26,27]$. The poorer prognosis of the male breast carcinoma might be related to ineffective therapies which do not consider these differences in the biological profile of the male tumor. Prognostic and predictive tis- sutal markers, detected by immunocytochemical methods and useful for therapeutic programming in the female breast cancer have a different significance in the male breast cancer and stress the need for different therapeutic strategies specific for male breast cancer.

\section{Conclusion}

More research is needed on male breast cancer as it becomes more apparent that it is a different disease than its female counterpart. This recognition will provide better-focused treatment strategies and improved survival, and will perhaps even provide us with a better understanding of breast carcinogenesis both in men and women.

\section{List of abbreviations}

MBC: male breast cancer; FBC: female breast cancer; DCIS: ductal carcinoma in situ; ER: estrogen receptor; PR: profesterone receptor.

\section{Consent}

Written informed consent was obtained from the patient for publication of this case report and accompanying images. A copy of the written consent is available for review by the Editor in Chief of this journal.

\section{Competing interests}

The authors declare that they have no competing interests.

\section{Authors' contributions}

DP conceived the study and participated in the design and writing of the report. ET and $\mathrm{AB}$ made the final diagnosis and helped to draft the manuscript. PV carried out the immunoassay; KC made the critical appraisal. KC was the attending physician.

\section{References}

I. Dhiab BT, Bouzid T, Gamoudi A, Hassouna JB, Khomsi F, Boussen H, Benna F, El May A, Hechiche M, Rahal K: Male breast cancer: about 123 cases collected at the Institute Salah-Azaiz of Tunis from 1979 to 1999. Bull Cancer 2005, 92:28I-285.

2. Muir D, Kanthan R, Kanthan SC: Male versus female breast cancers. A population-based comparative immunohistochemical analysis. Arch Pathol Lab Med 2003, I 27:36-4I.

3. Weiss JR, Moysich KB, Swede H: Epidemiology of male breast cancer. Cancer Epidemiol Biomarkers Prev 2005, I 4:20-26.

4. Hayes R, Cummings B, Miller RA, Guha AK: Male Paget's disease of the breast. Cutan Med Surg 2000, 4:208-2I 2.

5. Kollmorgen DR, Varanasi JS, Edge SB, Carson WE 3rd: Paget's disease of the breast: a 33-year experience. J Am Coll Surg 1998, 187:|7|-I77.

6. Bodnar M, Miller OF, Tyler W: Paget's disease of the male breast associated with intraductal carcinoma. J Am Acad Dermatol 1999, 40:829-831.

7. Gupta RK, Naran S, Lallu S, Fauck R: Needle aspiration cytodiagnosis of mucinous (colloid) carcinoma of male breast. Pathology 2004, 35:539-540.

8. Hodgson NC, Button JH, Franceschi D, Moffat FL, Livingstone AS: Male breast cancer: is the incidence increasing? Ann Surg Oncol 2004, I I:75 I-755. 
9. Nayak SK, Naik R, Upadhyaya K, Raghuveer CV, Pai MR: FNAC diagnosis of mucinous carcinoma of male breast - a case report. Indian J Pathol Microbiol 200I, 44:355-357.

10. Giordano SH, Buzdar AU, Hortobagyi GN: Breast cancer in men. Ann Intern Med 2002, 137:678-687.

II. Buzdar AU: Breast cancer in men. Oncology (Williston Park) 2003, I 7:| 36I-I364.

12. Kidmas AT, Ugwu BT, Manasseh AN, lya D, Opaluwa AS: Male breast malignancy in Jos university teaching hospital. West Afr J Med 2005, 24:36-40.

13. Olsson H: Estrogen receptor content in malignant breast tumors in men-a review. J Mammary Gland Biol Neoplasia 2000, 5:283-287.

14. Munoz de Toro MM, Maffini MV, Kass L, Luque EH: Proliferative activity and steroid hormone receptor status in male breast carcinoma. J Steroid Biochem Mol Biol 1998, 67:333-339.

15. Rayson D, Erlichman C, Suman VJ, Roche PC, Wold LE, Ingle JN, Donohue $\mathrm{J}$ : Molecular markers in male breast carcinoma. Cancer 1998, 83:1947-1955.

16. Friedman MA, Hoffman PG Jr, Dandolos EM, Dandolos EM, Lagios $M D$, Johnston WH, Siiteri PK: Estrogen receptors in male breast cancer: clinical and pathologic correlations. Cancer 1981, 47:134-137.

17. Nixon AJ, Neuberg D, Hayes DF, Gelman R, Connolly JL, Schnitt S, Abner A, Recht A, Vicini F, Harris JR: Relationship of patient age to pathologic features of the tumor and prognosis for patients with stage I or II breast cancer. J Clin Oncol 1994, 1 2:888-894.

18. Joshi MG, Lee AK, Loda M, Camus MG, Pedersen C, Heatley GJ, Hughes KS: Male breast carcinoma: an evaluation of prognostic factors contributing to a poorer outcome. Cancer 1996, 177:490-498.

19. Kidwai N, Gong Y, Sun X, Deshpande CG, Yeldandi AV, Rao MS, Badve S: Expression of androgen receptor and prostate-specific antigen in male breast carcinoma. Breast Cancer Res 2004, 6:R18-R23.

20. Salvadori B, Saccozzi R, Manzari A, Andreola S, Conti RA, Cusumano $F$, Grassi M: Prognosis of breast cancer in males: an analysis of 170 cases. Eur J Cancer 1994, 30:930-935.

21. Aghadiuno PU: Cancer of the male breast: analysis of fortythree cases in Ibadan, Nigeria. Afr J Med Med Sci 1987, 16(I):15-26

22. Borgen PI, Senie RT, McKinnon WM, Rosen PP: Carcinoma of the male breast: analysis of prognosis compared with matched female patients. Ann Surg Oncol 1997, 4:385-388.

23. Cutuli B, Lacroze M, Dilhuydy JM, Velten M, De Lafontan B, Marchal C, Resbeut M, Graic Y, Campana F, Moncho-Bernier V: Male breast cancer: results of the treatments and prognostic factors in 397 cases. Eur J Cancer 1995, 31:1960-1964.

24. Gadenne C, Contesso G, Travagli JP, Rouesse J, Fontaine F: Male breast tumours. Anatomico-clinical study based on 73 cases (author's transl). Nouv Presse Med 1982, I I (31):233I-2334.

25. Bergs EA, Tanis PJ, Steller EP: Three men with breast cancer. Ned Tijdschr Geneeskd 2005, 149:534-537.

26. Barlund M, Kuukasjarvi T, Syrjakoski K, Auvinen A, Kallioniemi A: Frequent amplification and overexpression of CCNDI in male breast cancer. Int J Cancer 2004, I I I:968-97I.

27. Petroni S, Mangia A, D'Amico C, Simone G: Expression of steroid receptors and DNA synthesis in male breast cancer. Pathologica 2003, 95:31-36.
Publish with Biomed Central and every scientist can read your work free of charge

"BioMed Central will be the most significant development for disseminating the results of biomedical research in our lifetime. "

Sir Paul Nurse, Cancer Research UK

Your research papers will be:

- available free of charge to the entire biomedical community

- peer reviewed and published immediately upon acceptance

- cited in PubMed and archived on PubMed Central

- yours - you keep the copyright

Submit your manuscript here:

http://www.biomedcentral.com/info/publishing_adv.asp
BiolMedcentral 